\title{
Presynaptic Release Probability and Readily Releasable Pool Size Are Regulated by Two Independent Mechanisms during Posttetanic Potentiation at the Calyx of Held Synapse
}

\author{
Jae Sung Lee, Myoung-Hwan Kim, Won-Kyung Ho, and Suk-Ho Lee \\ National Research Laboratory for Cell Physiology, Department of Physiology, Seoul National University College of Medicine and Neuroscience Research \\ Institute, Seoul National University Medical Research Center, Seoul 110-799, Korea
}

At the immature calyx of Held, the fast decay phase of a $\mathrm{Ca}^{2+}$ transient induced by tetanic stimulation (TS) was followed by a period of elevated $\left[\mathrm{Ca}^{2+}\right]_{\mathrm{i}}$ for tens of seconds, referred to as posttetanic residual calcium $\left(\mathrm{Ca}_{\text {res }}\right)$. We investigated the source of $\mathrm{Ca}_{\text {res }}$ and its contribution to posttetanic potentiation (PTP). After TS ( $100 \mathrm{~Hz}$ for 4 s), posttetanic $\mathrm{Ca}_{\text {res }}$ at the calyx of Held was largely abolished by tetraphenylphosphonium $\left(\mathrm{TPP}^{+}\right)$or Ru360, which inhibit mitochondrial $\mathrm{Na}^{+}$-dependent $\mathrm{Ca}^{2+}$ efflux and $\mathrm{Ca}^{2+}$ uniporter, respectively. Whereas the control PTP lasted longer than $\mathrm{Ca}_{\text {res }}$, inhibition of $\mathrm{Ca}_{\text {res }}$ by TPP ${ }^{+}$resulted in preferential suppression of the early phase of PTP, the decay time course of which well matched with that of $\mathrm{Ca}_{\text {res }}$. TS induced significant increases in release probability $\left(P_{\mathrm{r}}\right)$ and the size of the readily releasable pool (RRP), which were estimated from plots of cumulative EPSC amplitudes. TPP ${ }^{+}$or Ru360 suppressed the posttetanic increase in $P_{\mathrm{r}}$, whereas it had little effect on the increase in RRP size. Moreover, the posttetanic increase in $P_{\mathrm{r}}$, but not in RRP size, showed a linear correlation with the amount of $\mathrm{Ca}_{\text {res }}$. In contrast, myosin light chain kinase (MLCK) inhibitors and blebbistatin reduced the posttetanic increase in RRP size with no effect on the increase in $P_{\mathrm{r}}$. Application of TPP ${ }^{+}$in the presence of MLCK inhibitor peptide caused further suppression of PTP. These findings suggest that $\mathrm{Ca}_{\text {res }}$ released from mitochondria and activation of MLCK are primarily responsible for the increase in $P_{\mathrm{r}}$ and that in the RRP size, respectively.

Key words: posttetanic potentiation; residual calcium; mitochondria; myosin light chain kinase; readily releasable pool; calyx of Held

\section{Introduction}

Posttetanic potentiation (PTP) is a transient enhancement of synaptic efficacy that lasts tens of seconds after a cessation of tetanic stimulation (TS). It is generally accepted that PTP is presynaptic in origin (for review, see Zucker and Regehr, 2002). The posttetanic residual calcium $\left(\mathrm{Ca}_{\text {res }}\right)$ has been a long-standing hypothesis for PTP mechanisms (Kamiya and Zucker, 1994). A linear relationship between the magnitudes of PTP and $\mathrm{Ca}_{\text {res }}$ concentration has been demonstrated at the calyx of Held (Habets and Borst, 2005; Korogod et al., 2005). Although a close temporal correlation between posttetanic recovery of presynaptic $\mathrm{Ca}^{2+}$ concentration $\left(\left[\mathrm{Ca}^{2+}\right]_{\mathrm{i}}\right)$ and synaptic enhancement during PTP has been shown at crayfish neuromuscular junctions (NMJs) (Delaney et al., 1989; Delaney and Tank, 1994), it has been recognized that the time course of $\left[\mathrm{Ca}^{2+}\right]_{\mathrm{i}}$ decay is faster than that of PTP at mammalian central synapses, suggesting that PTP is not

Received June 24, 2008; revised June 5, 2008; accepted June 13, 2008.

This work was supported by a grant (M103KV010008-06K2201-00810) from Brain Research Center of the 21st Century Frontier Research Program funded by the Ministry of Science and Technology, the Republic of Korea. J.S.L. is a postgraduate student supported by Program BK21 from the Ministry of Education. We are grateful to Drs. Neher and Sakaba for critical reading of this manuscript.

Correspondence should be addressed to Dr. Suk-Ho Lee, Department of Physiology, Seoul National University College of Medicine, Chongno-Ku, Yongon-Dong 28, Seoul 110-799, Korea. E-mail address: leesukho@snu.ac.kr.

M.-H. Kim's present address: Department of Biological Sciences, Korea Advanced Institute of Science and Technology, Daejeon 305-701, Korea.

DOI:10.1523/JNEUROSCI.2165-08.2008

Copyright $\odot 2008$ Society for Neuroscience $\quad$ 0270-6474/08/287945-09\$15.00/0 solely dictated by $\mathrm{Ca}_{\text {res }}$ (Regehr et al., 1994; Korogod et al., 2005) (but see Habets and Borst, 2005). To account for the temporal mismatch between the $\mathrm{Ca}_{\text {res }}$ and PTP, a calcium binding site with slow kinetics has been assumed, but its identity remains elusive (Regehr et al., 1994).

Presynaptic release of synaptic vesicles is largely determined by both the readily releasable pool (RRP) size and release probability $\left(P_{\mathrm{r}}\right)$. Recently, it has been shown that increases in both $P_{\mathrm{r}}$ and the RRP size contribute to PTP at the calyx of Held synapse and that the increase in RRP size lasts longer than that in $P_{\mathrm{r}}$ (Habets and Borst, 2007). Interestingly, submicromolar elevation of basal $\left[\mathrm{Ca}^{2+}\right]_{\mathrm{i}}(<100 \mathrm{nM})$ induced by a small depolarization of the calyceal terminal caused a significant increase in $P_{\mathrm{r}}$ with no effect on the RRP size (Awatramani et al., 2005), implying that $\mathrm{Ca}_{\text {res }}$ may have differential effects on the posttetanic increase in $P_{\mathrm{r}}$ and in the RRP size. We investigated the source of $\mathrm{Ca}_{\text {res }}$ at the calyx of Held, and assessed contribution of $\mathrm{Ca}_{\text {res }}$ to the posttetanic increases in $P_{\mathrm{r}}$ and in the RRP size, which were estimated from the plot of cumulative EPSC amplitudes (Schneggenburger et al., 1999). We found that $\mathrm{Ca}_{\text {res }}$ is generated mainly by posttetanic release from mitochondria at the calyx of Held. When mitochondrial $\mathrm{Ca}^{2+}$ release was inhibited to reduce $\mathrm{Ca}_{\text {res }}$, the increase in $P_{\mathrm{r}}$, but not the RRP size, was affected. In contrast, inhibitors of myosin light chain kinase (MLCK) reduced specifically the posttetanic increase in the RRP size. 


\section{Materials and Methods}

Preparation of brainstem slices. Transverse 180 - to 200 - $\mu$ m-thick brainstem slices containing the medial nucleus of trapezoid body (MNTB) were prepared from 6- to 8-d-old Sprague Dawley rats (17 $\pm 8 \mathrm{~g}$ ). Rats were decapitated, and brainstems were chilled in ice-cold low-calcium artificial CSF (aCSF), which contained (in mM) $125 \mathrm{NaCl}, 25 \mathrm{NaHCO}_{3}$, $2.5 \mathrm{KCl}, 1.25 \mathrm{NaH}_{2} \mathrm{PO}_{4}, 2.5 \mathrm{MgCl}_{2}, 0.5 \mathrm{CaCl}_{2}, 25$ glucose, $0.4 \mathrm{Na}$ ascorbate, 3 myoinositol, and $2 \mathrm{Na}$ pyruvate $[\mathrm{pH} 7.4$ when saturated with carbogen $\left(95 \% \mathrm{O}_{2}, 5 \% \mathrm{CO}_{2}\right)$; osmolarity, $\left.320 \mathrm{mOsm}\right]$. Brainstem slices were made with a vibratome slicer (VT1000S; Leica), and slices were incubated at $37^{\circ} \mathrm{C}$ for $30 \mathrm{~min}$ in normal aCSF, the constituents of which are the same as low-calcium aCSF except $1 \mathrm{~mm} \mathrm{MgCl}_{2}$ and $2 \mathrm{~mm}$ $\mathrm{CaCl}_{2}$, and thereafter maintained at room temperature $\left(23-25^{\circ} \mathrm{C}\right)$ until required.

Electrophysiological recording and reagents. Slices were transferred to a recording chamber in an upright microscope (BX50WI; Olympus). Whole-cell patch-clamp recordings from calyces of Held were made under visual control using differential interference illumination. In most experiments, to reduce saturation and desensitization of AMPA receptors, we added $1 \mathrm{~mm}$ kynurenic acid (Kyn; Tocris) or $4 \mathrm{~mm} \gamma$-Dglutamylglycine ( $\gamma$-DGG) to aCSF, which were denoted as "aCSF + Kyn" or "aCSF $+\gamma$-DGG," respectively, in Results. To preload calyx terminals with $\mathrm{Ca}^{2+}$ indicator dye, we made a brief presynaptic whole-cell recording for $\sim 90 \mathrm{~s}$ with the K-gluconate-containing pipette solution composed of (in mM) $120 \mathrm{~K}$-gluconate, $30 \mathrm{KCl}, 20 \mathrm{HEPES}, 4 \mathrm{Na}_{2}$ phosphocreatine, $4 \mathrm{Mg}$-ATP, $0.3 \mathrm{Na}-\mathrm{GTP}$, and 0.2 fura-4F. The "preloading" technique was also used for delivering lipid-soluble drugs into the cytosol of calyx terminals, because it took too long a time $(>50$ $\mathrm{min}$ ) for lipid-soluble drugs to take an effect, and drug effects were often too variable, when they were applied to the bath. Therefore, lipid-soluble drugs including blebbistatin, chelerythrine, Bis-I, and Bis-V were dissolved in dimethylsulfoxide (DMSO) and added to the internal solution such that final concentration of DMSO became 1:1000 (v/v). In these cases, the synapse whose calyx terminal was preloaded with vehicle only (DMSO) was regarded as a control. Postsynaptic recordings were made in voltage-clamp mode at a holding potential of $-70 \mathrm{mV}$. Series resistance $\left(R_{s}\right.$; range, $\left.4-15 \mathrm{M} \Omega\right)$ was regularly checked and partially compensated by up to $75 \%$ for remaining uncompensated $R_{\mathrm{s}}$ value of 3-4 M $\Omega$. Experiments were discarded when uncompensated $R_{\mathrm{s}}$ exceeded $15 \mathrm{M} \Omega$. Patch pipettes with a resistance of 3.5-4.5 $\mathrm{M} \Omega$ were used for recordings. Postsynaptic patch pipettes contained the following (in mM): 110 Csgluconate, 20 tetraethylammonium-Cl, $10 \mathrm{NaCl}, 20$ HEPES, 10 EGTA, 4 Mg-ATP, $5 \mathrm{Na}_{2}$-phosphocreatine, 5 lidocaine $\mathrm{N}$-ethyl bromide (QX314; an intracellular blocker of $\mathrm{Na}^{+}$currents), $\mathrm{pH} 7.3$ (adjusted with $\mathrm{CsOH}$ ). Recordings were made at room temperature $\left(23-25^{\circ} \mathrm{C}\right)$ with an EPC10 amplifier (HEKA). EPSCs were evoked by stimulating presynaptic axons $(0.1-0.2 \mathrm{~ms}, 10-20 \mathrm{~V})$ with a bipolar stimulating electrode (TM53CCINSl; World Precision Instruments) placed at the midline of the brainstem. Fura-4F was purchased from Invitrogen. Ru360, ML-7, myosin light chain kinase inhibitor peptide 18 (MLCKip), Ro31-8220, Bis-1, and Bis-5 were obtained from Merck Biosciences. Kynurenate, $\gamma$-DGG, QX314, and cyclothiazide were purchased from Tocris. Blebbistatin was from Biomol. Other reagents, including tetraphenylphosphonium $\left(\mathrm{TPP}^{+}\right)$, were purchased from Sigma.

Presynaptic $\left[\mathrm{Ca}^{2+}\right]$ imaging. Calyces of Held were preloaded with 200 $\mu \mathrm{M}$ fura-4F for typically $90 \mathrm{~s}$ via presynaptic whole-cell recording with the K-gluconate solution. After withdrawing the patch pipette, $\left[\mathrm{Ca}^{2+}\right]_{\mathrm{i}}$ at the calyx of Held was measured as previously described (Kim et al., 2005). Briefly, excitation light from a monochromator (Polychrome-II; TILL Photonics) was delivered to an upright microscope (BX50; Olympus). Imaging was performed using a $60 \times$ water-immersion objective (numerical aperture, 0.9; LUMPlanFl; Olympus) and an air-cooled slowscan CCD camera (SensiCam; PCO) using on-chip binning $(8 \times 16$ pixels). The fluorescence ratio $\left(r=F_{\text {iso }} / F_{380}\right)$ at the isosbestic wavelength $\left(360 \mathrm{~nm} ; F_{\text {iso }}\right)$ to that at $380 \mathrm{~nm}\left(F_{380}\right)$ was converted to $\left[\mathrm{Ca}^{2+}\right]_{\mathrm{i}}$ according to the following equation:

$$
\left[\mathrm{Ca}^{2+}\right]_{\mathrm{i}}=K_{\mathrm{eff}} \times\left(R-R_{\min }\right) /\left(R_{\max }-R\right) .
$$

Calibration parameters were determined by "in-cell" calibration. $R_{\min }$ values were measured using a $\mathrm{Ca}^{2+}$-free internal solution containing 10 mM BAPTA. $R_{\max }$ values were obtained from in vitro measurement, because calyces of Held did not endure internal dialysis with high $\mathrm{CaCl}_{2}(10$ $\mathrm{mm})$. The values for the calibration ratio at intermediate $\left[\mathrm{Ca}^{2+}\right]_{\mathrm{i}}$ were measured in the calyx using a pipette solution containing $8 \mathrm{~mm}$ BAPTA and $6 \mathrm{mM} \mathrm{CaCl}_{2}\left(\left[\mathrm{Ca}^{2+}\right]_{\mathrm{i}} \approx 660 \mathrm{nM}\right)$ for fura-4F. The effective dissociation constant of fura- $4 \mathrm{~F}\left(K_{\text {eff }}\right)$ was calculated by measuring the fluorescence ratio at these intermediate $\left[\mathrm{Ca}^{2+}\right]_{\mathrm{i}}$ and by rearranging Equation 1 for $K_{\text {eff }}$. The $K_{\mathrm{d}}$ values of fura- $4 \mathrm{~F}$ were calculated as $0.75 \mu \mathrm{M}$ from $K_{\mathrm{d}}=$ $K_{\text {eff }} \times\left(\alpha+R_{\min }\right) /\left(\alpha+R_{\max }\right)$, where $\alpha$ is the iso-coefficient. All the estimates of presynaptic $\left[\mathrm{Ca}^{2+}\right]$ were presented as an excursion of $\left[\mathrm{Ca}^{2+}\right]_{\mathrm{i}}\left(\Delta\left[\mathrm{Ca}^{2+}\right]_{\mathrm{i}}\right)$ from its resting level ranging from 100 to $200 \mathrm{nM}$. The decay phase of a $\mathrm{Ca}^{2+}$ transient induced by TS $(100 \mathrm{~Hz}$ for $4 \mathrm{~s})$ is characterized by a period of slow $\left[\mathrm{Ca}^{2+}\right]$ decay that lasted tens of seconds. Henceforth, we define posttetanic residual $\left[\mathrm{Ca}^{2+}\right]$ as $\Delta\left[\mathrm{Ca}^{2+}\right]_{\mathrm{i}}$ during the slow decay phase after a fast decay phase of a $\mathrm{Ca}^{2+}$ transient induced by TS. The amount of $\mathrm{Ca}_{\text {res }}$ was quantified as the time integral of $\Delta\left[\mathrm{Ca}^{2+}\right]_{\mathrm{i}}$ from $2 \mathrm{~s}$ after the end of TS for a period two times longer than the decay time constant of residual $\left[\mathrm{Ca}^{2+}\right]_{\mathrm{i}}$ (denoted by $\int \mathrm{Ca}_{\text {res }} \mathrm{d} t$ ).

Statistics and data presentation. Data are presented as mean \pm SEM, with $n$ indicating the number of synapses analyzed. In figures, the number of synapses or calyceal terminals that we studied is indicated as a number in parentheses on each bar. In Results, the first and the second statistical values in parentheses intervened by "vs" represent statistical data under control conditions and under test conditions, respectively. Statistical analyses on data measured at the same synapse and on data at different synapses were performed using the Student's paired $t$ test and the Student's $t$ test, respectively.

\section{Results}

\section{PTP results from increases in both the RRP size and $P_{\mathrm{r}}$ at the calyx of Held synapse}

We investigated PTP of EPSCs evoked by afferent fiber stimulation at the immature calyx of Held synapse of the rat (postnatal day 6-8). Unless otherwise mentioned, we monitored EPSCs evoked by paired stimuli (interstimulus interval $20 \mathrm{~ms}$ ) every $10 \mathrm{~s}$ in the presence of $1 \mathrm{~mm}$ Kyn to prevent desensitization and saturation of postsynaptic AMPA receptors. The mean basal EPSC amplitude was $1.53 \pm 0.20 \mathrm{nA}(n=11)$, which corresponds to $40 \pm 4.6 \%$ of that in the absence of $1 \mathrm{~mm} \mathrm{Kyn}$. At $20 \mathrm{~s}$ after TS ( $100 \mathrm{~Hz}$ train of $4 \mathrm{~s}$ duration), the EPSC amplitude increased by $100.33 \pm 10.6 \%(n=19)$ of control values (Fig. $1 E)$, and the paired-pulse ratio was reduced from $0.91 \pm 0.05$ to $0.42 \pm 0.03$ $(p<0.01)$ (Fig. 1A), indicative of a presynaptic locus of the PTP expression. When PTP was induced repeatedly at the same synapse, no progressive decline of PTP was observed. We assessed TS-induced relative changes in the RRP size and $P_{\mathrm{r}}$ by comparing a plot of cumulative amplitudes of first 20 EPSCs evoked by TS with that of EPSCs evoked by short trains of APs (100 Hz, 20 pulses) applied $20 \mathrm{~s}$ after TS (Fig. 1C,D). TS increased both estimates for the RRP size and $P_{\mathrm{r}}$ by $16.5 \pm 1.2 \%$ and by $70.6 \pm 9.0 \%$ of control values, respectively $(n=19 ; p<0.01$, paired $t$ test) (Fig. 1E).

To rigorously test whether the saturation and desensitization of AMPA receptors affected our estimates of relative changes in $P_{\mathrm{r}}$ and the RRP size, we repeated experiments in the presence of 2 mm Kyn or $4 \mathrm{~mm} \gamma$-DGG instead of $1 \mathrm{~mm}$ Kyn (Wong et al., 2003). All estimates for the RRP size and $P_{\mathrm{r}}$ and their changes after PTP induction under the different pharmacological conditions are summarized in supplemental Table 1 (available at www. jneurosci.org as supplemental material). We found that relative changes in the RRP size and $P_{\mathrm{r}}$ in the presence of $1 \mathrm{~mm}$ Kyn were not different from those in the presence of $2 \mathrm{~mm}$ Kyn or $4 \mathrm{~mm}$ $\gamma$-DGG (Fig. 1E). Therefore, we henceforth presented the statis- 
A
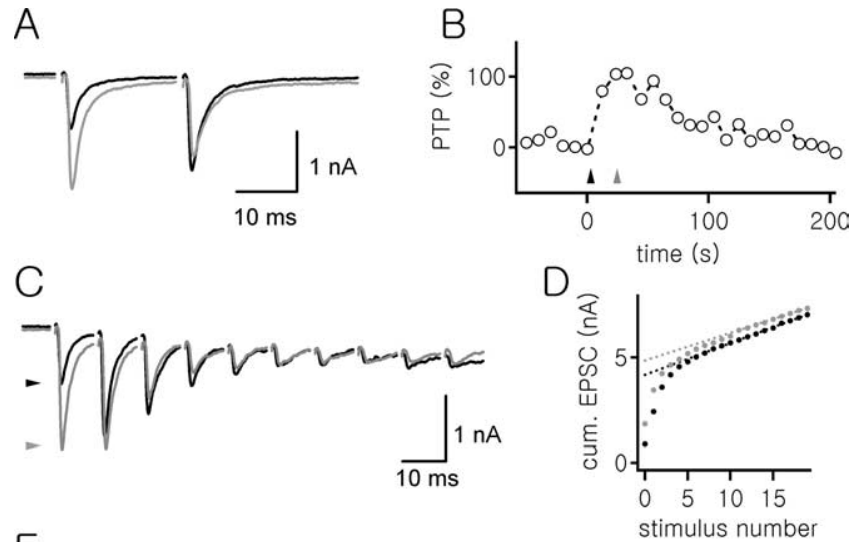

\section{E}

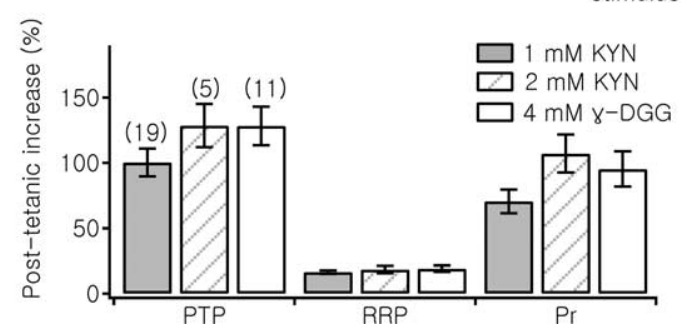

Figure 1. Changes in the RRP size and $P_{\mathrm{r}}$ during posttetanic potentiation at the calyx of Held synapse. $A$, EPSCs in response to a pair of fiber stimulation separated by $20 \mathrm{~ms}$ (aCSF $+\mathrm{Kyn}$ ). Baseline EPSC (black) and EPSC recorded after TS ( $100 \mathrm{~Hz}$ for $4 \mathrm{~s}$; gray) are superimposed. $\boldsymbol{B}$, Time course for PTP of EPSC amplitudes. Time points of TS and stimulation with a short train of action potentials (short AP trains; $100 \mathrm{~Hz}, 20$ pulses) are indicated by black and gray triangles, respectively. C, First 10 EPSCs induced by TS (black) or by short AP trains (gray) applied 20 s after the TS. D, Plot of cumulative (cum.) EPSC amplitudes evoked by TS (black circles) or by a short AP train shown in C. RRP size was estimated at the $y$-intercept of the back extrapolation line fitted to the last five points. $P_{r}$ was estimated from the first EPSC amplitude divided by the estimate of RRP size. Both $P_{r}$ and RRP were increased to $180 \%$ and $116 \%$ of control values, respectively. $\boldsymbol{E}$, Mean values for PTP and associated changes in $P_{r}$ and the RRP size measured $20 \mathrm{~s}$ after TS in the presence of $1 \mathrm{~mm} \operatorname{Kyn}(n=19), 2$ mм Kyn $(n=5)$, or 4 mм $\gamma$-DGG $(n=11)$. Data are mean \pm SEM.

tical data after pooling data obtained in the presence of $1 \mathrm{~mm} \mathrm{Kyn}$ and those in the presence of $4 \mathrm{~mm} \gamma$-DGG.

\section{Effects of mitochondrial $\mathrm{Na}^{+}$-dependent $\mathrm{Ca}^{2+}$ efflux inhibitor, $\mathrm{TPP}^{+}$, on $\mathrm{Ca}_{\text {res }}$ and PTP}

It has been demonstrated that the magnitude of PTP is linearly correlated with that of residual $\left[\mathrm{Ca}^{2+}\right]_{i}$ at the calyx of Held synapse (Habets and Borst, 2005; Korogod et al., 2005), but the source of $\mathrm{Ca}_{\text {res }}$ is not known at this synapse. Mitochondria have been suggested as a source of $\mathrm{Ca}_{\text {res }}$ at the motor nerve terminals and at large terminals of hippocampal mossy fibers (Tang and Zucker, 1997; García-Chacón et al., 2006; Lee et al., 2007). TPP ${ }^{+}$ at low concentration $\left(\mathrm{IC}_{50}, 0.2 \mu \mathrm{M}\right.$ ) (Wingrove and Gunter, $1986)$ is known as a potent and selective inhibitor of mitochondrial $\mathrm{Na}^{+}$-dependent $\mathrm{Ca}^{2+}$ efflux (NCE) with little adverse effects on mitochondrial respiration (Aiuchi et al., 1985). To test whether mitochondrial NCE contributes to presynaptic $\mathrm{Ca}_{\text {res }}$, we studied the effects of $2 \mu \mathrm{M} \mathrm{TPP}{ }^{+}$on presynaptic $\mathrm{Ca}_{\text {res }}$. For simultaneous recording of presynaptic $\left[\mathrm{Ca}^{2+}\right]$ and EPSCs, we loaded the calyx with $\mathrm{Ca}^{2+}$-indicator dye via whole-cell patch pipette containing $200 \mu \mathrm{M}$ fura-4F for a brief period ( $\sim 90 \mathrm{~s}$ ), and pulled off the pipette. Because of the fluorescence of Kyn at UV excitation, when combined with $\mathrm{Ca}^{2+}$ imaging, EPSCs were recorded in the presence of $4 \mathrm{~mm} \gamma$-DGG.

We compared the time courses of PTP and residual $\Delta\left[\mathrm{Ca}^{2+}\right]$ before and after bath application of $2 \mu \mathrm{M} \mathrm{TPP}{ }^{+}$at the same
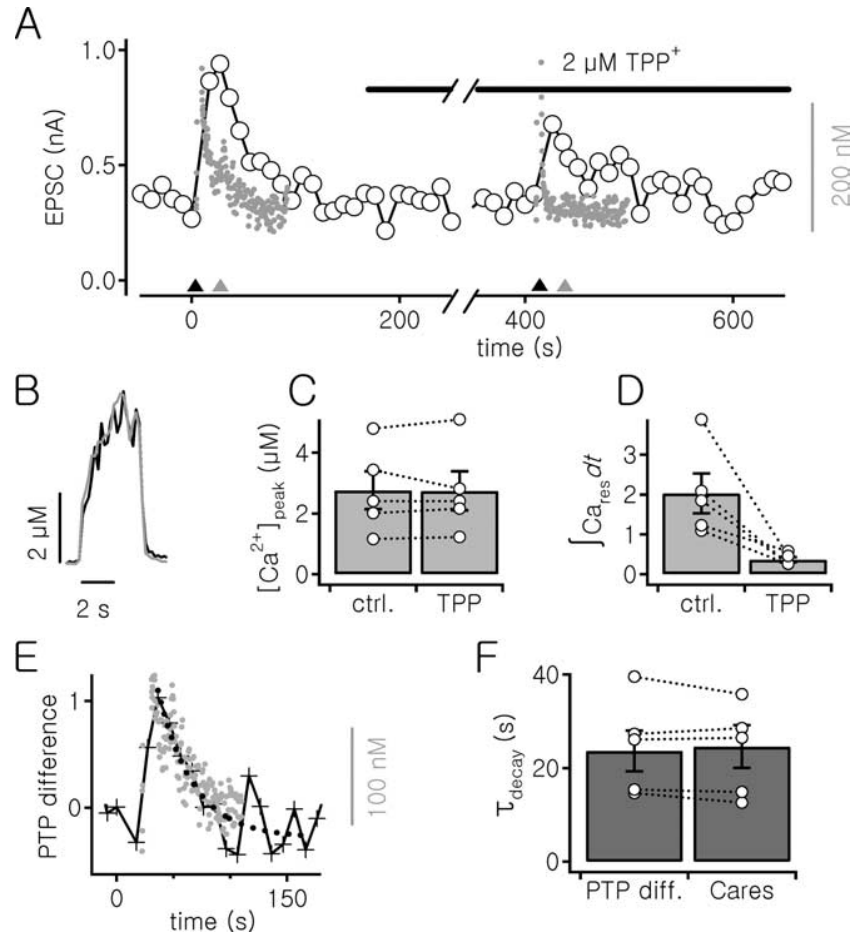

Figure 2. Effects of mitochondrial NCE inhibitor, TPP ${ }^{+}$, on PTP and presynaptic residual calcium $\left(\mathrm{Ca}_{\text {res }}\right)$ at the calyx of Held synapse. $\boldsymbol{A}$, Time-dependent changes in EPSC amplitude (open circles, left ordinate) and in presynaptic $\mathrm{Ca}_{\text {res }}$ (gray dots; calibration: $200 \mathrm{~nm}$ ) simultaneously recorded at the same synapse (aCSF $+\gamma$-DGG). TPP ${ }^{+}$reduced the time integrals of $\mathrm{Ca}_{\text {res }}$ from 3.89 to $0.46 \mu \mathrm{m} \cdot \mathrm{s} . \boldsymbol{B}, \mathrm{Ca}^{2+}$ transients during TS with expanded time scale (black, control; gray, $\left.\operatorname{TPP}^{+}\right) . \mathbf{C}, \boldsymbol{D}$, Mean values for peak $\left[\mathrm{Ca}^{2+}\right]$ of $\mathrm{Ca}^{2+}$ transients $(\boldsymbol{C})$ and time integral of $\mathrm{Ca}_{\text {res }}(\boldsymbol{D})$ induced by TS before and after bath application of TPP ${ }^{+}$. The estimate for $\int \mathrm{Ca}_{\text {res }} \mathrm{d} t$ was reduced from $2.03 \pm 0.50$ to $0.37 \pm 0.07 \mu \mathrm{m} \cdot \mathrm{s}(n=5 ; p=0.03)$, whereas the mean peak $\left[\mathrm{Ca}^{2+}\right]$ was little affected $(2.77 \pm 0.63 \mu \mathrm{m}$ and $2.75 \pm 0.64 \mu \mathrm{m}$ before and after application of TPP ${ }^{+}$, respectively; $\left.n=5 ; p=0.90\right) . \boldsymbol{E}_{\text {, TPP }}{ }^{+}$-sensitive PTP (solid line) and $\mathrm{Ca}_{\text {res }}$ (gray dots), calculated from $\boldsymbol{A}$, decayed with a similar time course (dotted line, an exponential fit to TPP ${ }^{+}$-sensitive PTP with $\tau=39.54 \mathrm{~s} ; \tau$ for $\left(a_{\text {res }}=35.78 \mathrm{~s}\right)$. $\boldsymbol{F}$, Mean values for decay time constants $(\tau)$ of TPP ${ }^{+}$-sensitive PTP $(\tau=23.66 \pm 4.34 s ; n=5)$ and residual $\Delta\left[\mathrm{Ca}^{2+}\right]_{\mathrm{i}}(\tau=24.61 \pm 4.56 \mathrm{~s} ; n=5)$. On the bar graphs $(\boldsymbol{C}, \boldsymbol{D}$, and $\boldsymbol{F})$, data points measured from the same synapse are connected with a dotted line.

synapse (Fig. $2 A)$. $\mathrm{TPP}^{+}$had little effect on the basal transmission $(0.52 \pm 0.15$ vs $0.49 \pm 0.15 \mathrm{nA} ; n=5 ; p=0.11$, paired $t$ test $)$, but significantly reduced PTP from $131.4 \pm 33.6$ to $53.4 \pm 10.3 \%$ $(n=5 ; p=0.04)$ (Figs. $2 A, 3 B a)$. Concomitantly, TPP $^{+}$essentially abolished posttetanic $\mathrm{Ca}_{\text {res }}$ (Fig. $2 A, D$ ), whereas the $\mathrm{Ca}^{2+}$ buildup during TS was not affected (Fig. $2 B, C$ ). In control conditions, there was a significant temporal mismatch between the decay time courses of PTP and accompanying residual $\Delta\left[\mathrm{Ca}^{2+}\right]_{\mathrm{i}}$ (Fig. $2 A$ ). The decay of $\mathrm{TPP}^{+}$-sensitive PTP (PTP in control conditions minus that in the presence of $\mathrm{TPP}^{+}$), however, occurred with a time course similar to the decay of residual $\Delta\left[\mathrm{Ca}^{2+}\right]_{\mathrm{i}}$ (Fig. $\left.2 E, F\right)$, indicative of a linear relationship between $\mathrm{Ca}_{\text {res }}$ and $\mathrm{TPP}^{+}$-sensitive PTP.

Next, we investigated which component of PTP, when comparing increases in $P_{\mathrm{r}}$ and in the RRP size, is affected by a reduction of $\int \mathrm{Ca}_{\text {res }} \mathrm{d} t$. TPP ${ }^{+}$significantly suppressed the posttetanic increase in $P_{\mathrm{r}}(94.3 \pm 25.7$ vs $26.9 \pm 6.4 \% ; n=5 ; p=0.04$ ) (Fig. $3 B b)$, whereas it had little effect on that in the RRP size $(18.7 \pm 2.4$ vs $19.6 \pm 3.2 \% ; p=0.63$ ) (Fig. $3 B c$ ). The posttetanic increase in $P_{\mathrm{r}}$, but not in the RRP size, showed a linear relationship with residual $\Delta\left[\mathrm{Ca}^{2+}\right]_{\mathrm{i}}(r=0.91)$ (Fig. $\left.3 C, D\right)$.

Saturation of intracellular $\mathrm{Ca}^{2+}$ buffer can greatly influence 


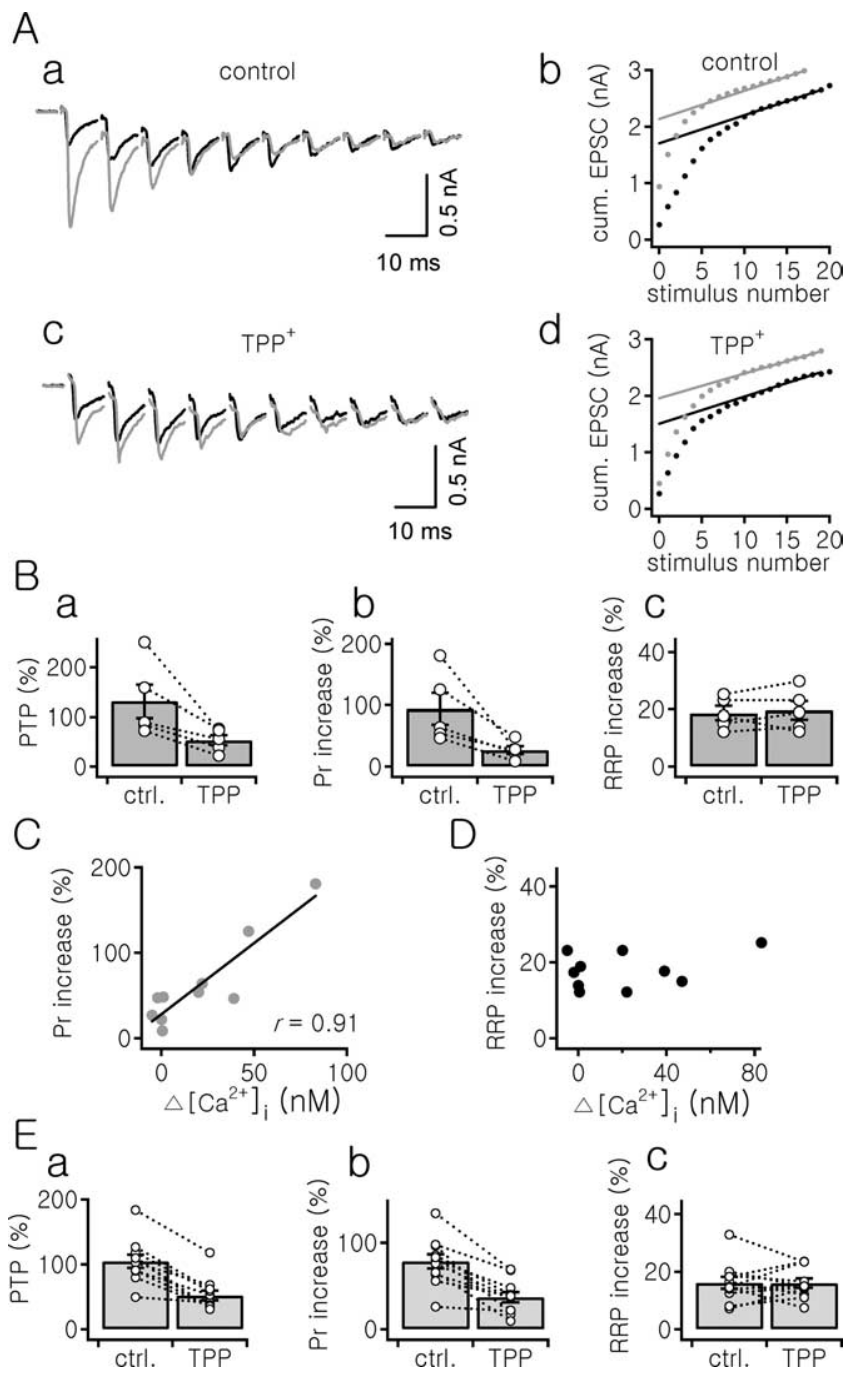

Figure 3. Effects of TPP ${ }^{+}$on posttetanic increases in $P_{\mathrm{r}}$ and in the RRP size. $\boldsymbol{A a}, \boldsymbol{A c}$, First 10 EPSCs induced by TS (black) or by a short AP train (gray) applied $20 \mathrm{~s}$ after the TS under control conditions (aCSF $+\gamma$-DGG; $\boldsymbol{A a}$ ) and in the presence of $2 \mu \mathrm{M} \mathrm{TPP}{ }^{+}(\boldsymbol{A c})$. $\boldsymbol{A} \boldsymbol{b}, \boldsymbol{A d}$, Plots of cumulative (cum.) EPSC amplitudes recorded before $(\boldsymbol{A} \boldsymbol{b})$ and after ( $\boldsymbol{A \boldsymbol { d }}$ ) the application of $\mathrm{TPP}^{+}$. EPSCs were recorded from the same synapse as in Figure $2 A$. The time points when these plots were obtained are indicated by triangles in Figure $2 A$ (black, TS; gray, $20 \mathrm{~s}$ after TS). The posttetanic increase in $P_{r}$ was reduced from 180.9 to $28.3 \%$ by TPP ${ }^{+}$, whereas the increase in RRP size was little affected (from 25.2 to 29.8\%). $B a-B C$, Summary of the effects of TPP ${ }^{+}$on PTP $(\boldsymbol{B} \boldsymbol{a})$ and increases in $P_{\mathrm{r}}(\boldsymbol{B} \boldsymbol{b})$ and in the RRP size $(\boldsymbol{B} \boldsymbol{c})$ under the "aCSF $+\gamma D \mathrm{DG}$ " condition. Dots connected with a dotted line indicate data obtained from the same synapse. $C, \boldsymbol{D}$, Plot of the posttetanic increase in $P_{r}(C)$ and in RRP size $(\boldsymbol{D})$ as a function of residual $\Delta\left[\mathrm{Ca}^{2+}\right]$. The increase in $P_{\mathrm{r}}$ was linearly correlated with $\mathrm{Ca}_{\mathrm{res}}(r=0.91)$. Ea-Ec, Mean values for PTP $(\boldsymbol{E a})$ and increases in $P_{\mathrm{r}}(\boldsymbol{E} \boldsymbol{b})$ and in the RRP size $(\boldsymbol{E} \boldsymbol{c})$ measured at the calyx of Held synapse, whose presynaptic terminal had not been preloaded with $\mathrm{Ca}^{2+}$ indicator dye (ctrl, under control conditions, aCSF $+\operatorname{Kyn}(n=5)$ or $\gamma$-DGG $(n=6) ; \operatorname{TPP}$, in the presence of $\left.2 \mu \mathrm{MPP}^{+}\right)$.

the release probability and thus short-term plasticity (Felmy et al., 2003). To test whether the presence of exogenous $\mathrm{Ca}^{2+}$ buffer exaggerates PTP by the buffer saturation mechanism (Rozov et al., 2001), we assessed the effects of $\mathrm{TPP}^{+}$on PTP under the conditions not disturbed by $\mathrm{Ca}^{2+}$-indicator dye and in the presence of $1 \mathrm{~mm}$ Kyn or $4 \mathrm{~mm} \gamma$-DGG. TPP ${ }^{+}$showed similar effects on the posttetanic increases in $P_{\mathrm{r}}$ and the RRP size, regardless of presynaptic loading with $\mathrm{Ca}^{2+}$-indicator dye (Fig. $3 E$ ). $\mathrm{TPP}^{+}$ suppressed PTP from $104.8 \pm 10.1$ to $52.3 \pm 7.6 \%[n=11 ; p<$ 0.01 , paired $t$ test; aCSF $+\operatorname{Kyn}(n=5)$ or $\gamma$-DGG $(n=6)] . \mathrm{TPP}^{+}$ exerts its effect on PTP by suppressing the posttetanic increase in
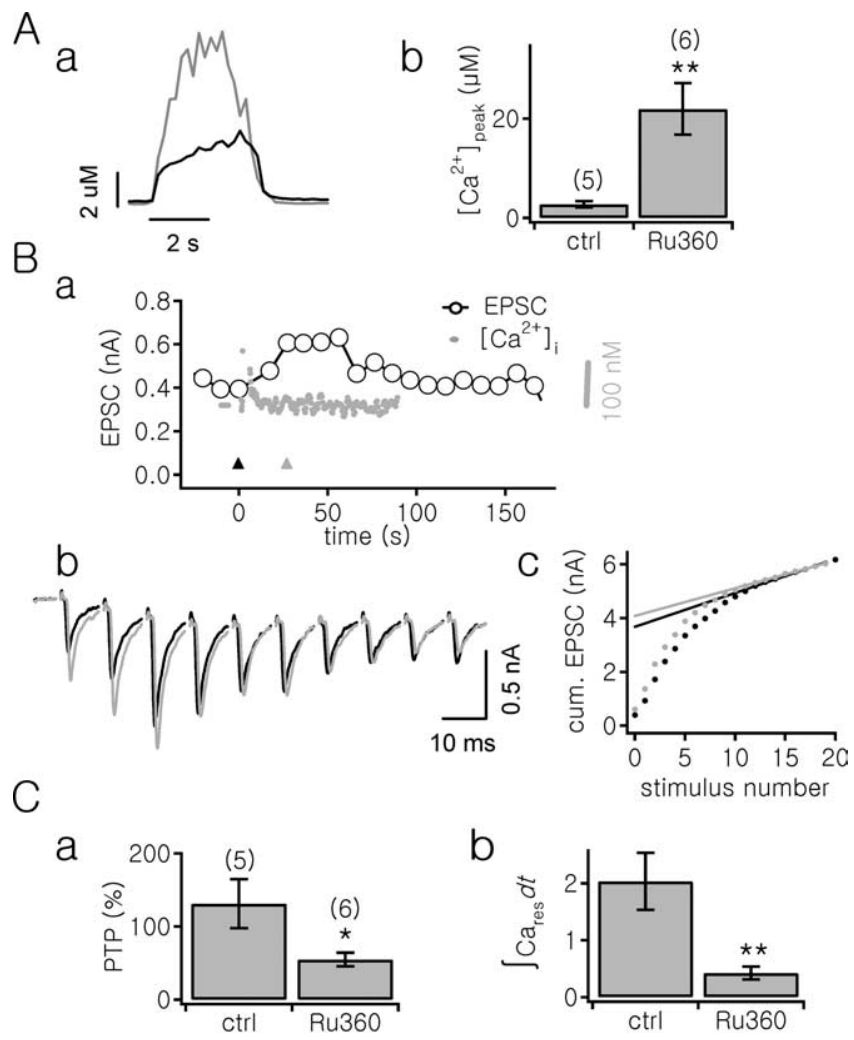

$\mathrm{b}$
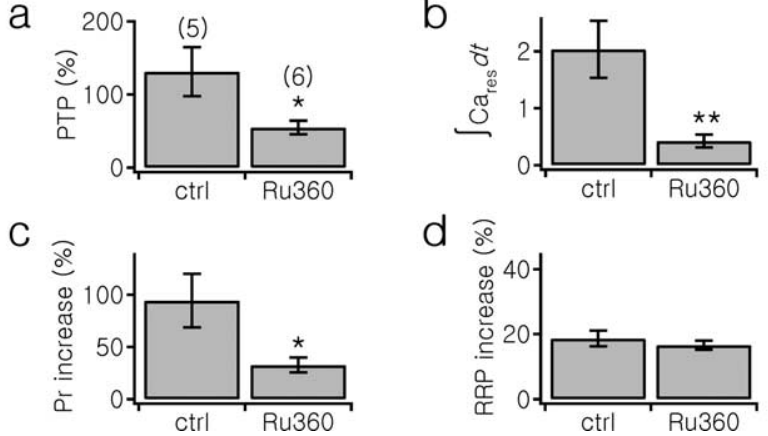

Figure 4. Effects of Ru360 on presynaptic $\mathrm{Ca}^{2+}$ dynamics and PTP. The calyx of Held was preloaded with Ru360 (20 $\mu \mathrm{m})$ together with fura-4F (200 $\mu \mathrm{m})$. Aa, $\boldsymbol{A} \boldsymbol{b}$, Representative $\mathrm{Ca}^{2+}$ transients $(\mathbf{A a})$ induced by the same $\mathrm{TS}(100 \mathrm{~Hz}, 4 \mathrm{~s})$ and mean values for peak $\left[\mathrm{Ca}^{2+}\right]$ of $\mathrm{Ca}^{2+}$ transients $(\boldsymbol{A} \boldsymbol{b})$ under control conditions (black trace) and in the presence of Ru360 (gray trace). $B \boldsymbol{a}$, Time course of EPSC amplitude (open circles, left ordinate) and $\mathrm{Ca}_{\text {res }}$ (gray dots, right calibration bar) at the calyx of Held preloaded with Ru360 (aCSF $+\gamma$-DGG). Triangles indicate time points when TS ( $100 \mathrm{~Hz}, 4 \mathrm{~s}$; black) or a short AP train ( $100 \mathrm{~Hz}, 20$ pulses; gray) was applied. $\boldsymbol{B} \boldsymbol{b}$, First 10 EPSCs during (black) and $20 \mathrm{~s}$ after TS (gray). BC, Plots of cumulative (cum.) EPSC amplitudes during (black) and $20 \mathrm{~s}$ after (gray) TS. RRP and $P_{\mathrm{r}}$ were increased by 11.1 and $39.0 \%$ of control values, respectively. $\mathbf{C a}-\boldsymbol{C d}$, Mean values for PTP $(\boldsymbol{C a})$, amount of presynaptic $\mathrm{Ca}_{\text {res }}$ $(\boldsymbol{C b})$, and increases in the $P_{\mathrm{r}}(\boldsymbol{C} \boldsymbol{c})$ and in the RRP size $(\boldsymbol{C d})$ at control synapses (ctrl; aCSF + $\gamma$-DGG) and at those preloaded with $20 \mu \mathrm{m}$ Ru360. Data are mean \pm SEM; ${ }^{*} p<0.05 ;{ }^{* *} p<$ 0.01 ; unpaired $t$ test.

$P_{\mathrm{r}}(78.6 \pm 8.3$ vs $37.1 \pm 5.9 \% ; n=11 ; p<0.01)$ (Fig. $\left.3 E b\right)$, because $\mathrm{TPP}^{+}$did not suppress the posttetanic increase in RRP size $(16.1 \pm 2.1$ vs $16.0 \pm 1.6 \% ; n=11 ; p=0.96)$ (Fig. $3 E c)$.

\section{Effects of Ru360 on PTP and residual $\mathrm{Ca}^{2+}$}

Exposed to high $\left[\mathrm{Ca}^{2+}\right]_{\mathrm{i}}$, mitochondria take up $\mathrm{Ca}^{2+}$ via the mitochondrial $\mathrm{Ca}^{2+}$ uniporter at the calyx of Held (Billups and Forsythe, 2002; Kim et al., 2005). To test whether mitochondrial $\mathrm{Ca}^{2+}$ uptake during TS is a prerequisite for the generation of $\mathrm{Ca}_{\text {res }}$, we examined posttetanic $\mathrm{Ca}_{\text {res }}$ at the calyx of Held preloaded with $200 \mu \mathrm{M}$ fura-4F plus $20 \mu \mathrm{M}$ Ru360, a specific blocker of $\mathrm{Ca}^{2+}$ uniporter (Kirichok et al., 2004). The calyx terminal preloaded with Ru360 showed significantly higher $\left[\mathrm{Ca}^{2+}\right]$ increments during TS $(100 \mathrm{~Hz}, 4 \mathrm{~s} ; 2.77 \pm 0.63 \mu \mathrm{M}$ vs $21.97 \pm 5.21 \mu \mathrm{M}$; $p<0.01$ ) (Fig. 4A), whereas posttetanic $\mathrm{Ca}_{\text {res }}$ was almost abolished $[0.42 \pm 0.11 \mu \mathrm{M} \cdot s ; n=6 ; p<0.01]$ [Fig. $4 B a$ (gray dots), 
$\mathrm{Cb}$. These results indicate that mitochondrial $\mathrm{Ca}^{2+}$ uptake limits the $\mathrm{Ca}^{2+}$ build-up during TS, and is a prerequisite for $\mathrm{Ca}_{\text {res }}$. In the presence of presynaptic Ru360, the same TS $(100 \mathrm{~Hz}, 4 \mathrm{~s})$ induced significantly lower PTP than under control conditions $(55.0 \pm 9.3 \% ; n=6 ; p=0.04)$ (Fig. $4 C a)$, whereas the basal EPSC amplitude was not different from control values $[0.52 \pm 0.15 \mathrm{nA}$ $(n=5)$ vs $0.43 \pm 0.10 \mathrm{nA}(n=6) ; p=0.62]$. Lower PTP in the presence of Ru360 can be explained primarily by the lower increase in $P_{\mathrm{r}}(32.7 \pm 7.3 \% ; n=6 ; p=0.03)$ (Fig. $\left.4 C c\right)$, because the increase in RRP size was not different from control values (16.7 \pm $1.4 \% ; n=6 ; p=0.48$ ) (Fig. $4 C d$ ). These results further confirm that posttetanic increase in $P_{\mathrm{r}}$, but not in RRP size, depends on $\mathrm{Ca}_{\text {res }}$ at the calyx of Held synapse.

\section{MLCK inhibitors abolish specifically the posttetanic increase in RRP size}

MLCK has been suggested to mediate the mobilization of synaptic vesicles (SVs) in the reserve pool at the NMJ (Verstreken et al., 2005), but its role at hippocampal synapse is controversial (Ryan, 1999; Tokuoka and Goda, 2006). To test the involvement of MLCK in posttetanic change of the RRP size, we studied the effects of ML-7, a specific MLCK inhibitor, on PTP and TSinduced increase in the RRP size. ML-7 $(20 \mu \mathrm{M})$ suppressed PTP from $131.0 \pm 21.1$ to $75.4 \pm 10.2 \%[n=10 ; p<0.01$, paired $t$ test; aCSF + Kyn $(n=5)$ or $\gamma$-DGG $(n=5)]$ (Fig. $5 A a, B a)$. ML-7 abolished the posttetanic increase in the RRP size $(19.8 \pm 2.0$ vs $1.1 \pm 2.0 \% ; p<0.01$ ) (Fig. $5 B b$ ), but not the increase in $P_{\mathrm{r}}$ $(95.5 \pm 18.7$ vs $78.9 \pm 8.9 \% ; p=0.22)$ (Fig. $5 B c)$. ML-7 increased the basal EPSC amplitude by $28.5 \pm 12.1$ and $42.3 \pm 15.6 \%$ in the presence of Kyn or $\gamma$-DGG, respectively, probably because of recruitment of the fast-releasing SV pool (Srinivasan et al., 2008). This can result in occlusion of posttetanic increase in the RRP size. To further test whether MLCK is involved in the posttetanic increase of the RRP size, we investigated the effects of inhibitors for different steps of the signal transduction pathway involving MLCK: calmodulin inhibitor, MLCK inhibitory peptide, and myosin ATPase inhibitor.

Activation of MLCK requires binding of $\mathrm{Ca}^{2+} /$ calmodulin (CaM) to its regulatory segment (Kamm and Stull, 2001). Bath application of calmidazolium $(20 \mu \mathrm{M})$, a calmodulin antagonist, reduced PTP from $86.2 \pm 17.7$ to $59.9 \pm 12.7 \%(n=5 ; p=0.02$, paired $t$ test; aCSF + Kyn) (Fig. $5 \mathrm{Ca}$ ), whereas the basal EPSC amplitude was not significantly affected $(1.58 \pm 0.30 \mathrm{nA}$ vs $1.78 \pm 0.37 \mathrm{nA} ; p=0.1)$. Similar to ML-7, calmidazolium suppressed posttetanic increase in the RRP size (16.5 \pm 2.2 vs $5.7 \pm$ $2.5 \% ; p=0.02$ ) (Fig. 5Cb), with no effect on the posttetanic $P_{\mathrm{r}}$ increase $(60.0 \pm 15.1$ vs $52.2 \pm 11.0 \% ; p=0.4)$ (Fig. $5 C c)$.

MLCK phosphorylates the myosin regulatory light chain, which in turn enhances the myosin ATPase activity. Myosin II has been suggested to modulate neurotransmission at sympathetic neuron (Takagishi et al., 2005). To test whether myosin II is involved in the posttetanic increase in RRP size, $100 \mu \mathrm{M}$ blebbistatin, a specific myosin II ATPase inhibitor, was introduced into the presynaptic terminal using the preloading technique. The basal EPSC amplitude was significantly lower at the synapse preloaded with blebbistatin than that at synapse preloaded with vehicle only [1:1000 DMSO; $0.85 \pm 0.16 \mathrm{nA}(n=5)$ vs $0.35 \pm$ $0.09 \mathrm{nA}(n=6) ; p=0.02 ; \mathrm{aCSF}+\gamma$-DGG]. Blebbistatin abolished specifically the posttetanic increase in the RRP size (24.0 \pm 2.8 vs $0.35 \pm 1.8 \% ; p<0.01)$ with no significant effect on the increase in $P_{\mathrm{r}}(70.5 \pm 10.0$ vs $76.0 \pm 12.4 \% ; p=0.75)$ (Fig. $5 D$ ).

Next, we tested the effects of MLCKip. The inhibitory mechanism of MLCKip is based on the autoinhibitory sequence of
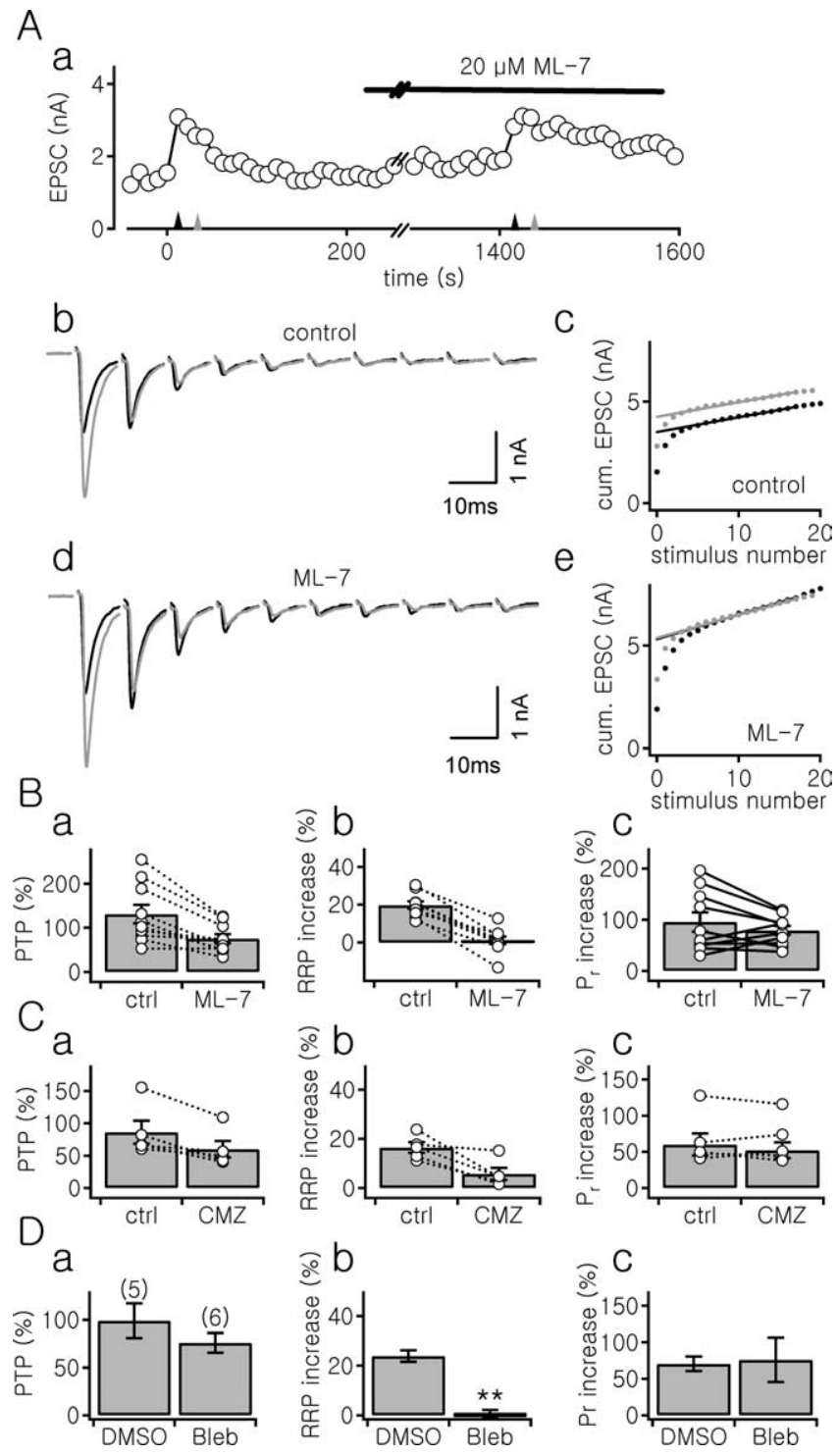

Figure 5. Inhibitors of MLCK or myosin ATPase abolished posttetanic increase in the RRP size with no significant effect on the increase in $P_{r}$. Aa, Time course of PTP before and 20 min after bath application of $20 \mu \mathrm{M} \mathrm{ML-7}$. Triangles indicate time points when TS ( $100 \mathrm{~Hz}$ for $4 \mathrm{~s}$; black) or short AP trains ( 20 pulses at $100 \mathrm{~Hz}$; gray) was applied. $\boldsymbol{A} \boldsymbol{b}, \boldsymbol{A d}$, First 10 EPSCs during (black) and 20 s after TS (gray) under control conditions ( $\boldsymbol{A} \boldsymbol{b}, \mathrm{aCSF}+\mathrm{Kyn}$ ) and in the presence of ML-7 (Ad). $A c, A e$, Plots of cumulative (cum.) EPSC amplitudes during (black) and $20 \mathrm{~s}$ after (gray) TS are superimposed under control conditions (Ac) and after application of ML-7 (Ae). ML-7 suppressed the increase in RRP size from 21.3 to $1.1 \%$, but the increase in $P_{r}$ was slightly enhanced (from 50.0 to $73.9 \%$ ). $\boldsymbol{B a}-\mathbf{C}$, Mean values for PTP ( $B \boldsymbol{a}, \boldsymbol{C a})$ and increases in the RRP size ( $\boldsymbol{B} \boldsymbol{b}$, (b) and $P_{r}(B C, C c)$ under control conditions (ctrl) and 20 min after the bath application of $20 \mu \mathrm{M}$ $\mathrm{ML}-7(\mathbf{B a}-\mathbf{B C})$ or $20 \mu \mathrm{m}$ calmidazolium (CMZ; $\mathbf{C a}-\mathbf{C c}) \cdot \mathbf{B a}-\mathbf{B C}$, aCSF + Kyn $(n=5)$ or $\gamma$-DGG $(n=5) ; \boldsymbol{C a}-\mathbf{C c}$, aCSF + Kyn $(n=5) . \boldsymbol{D a}-\mathbf{D c}$, Mean values for PTP $(\boldsymbol{D a})$ and increases in the RRP size $(\boldsymbol{D b})$ and in $P_{r}(\boldsymbol{D c})$ at the synapse preloaded with vehicle only (1:1000 DMSO; DMSO, aCSF $+\gamma$-DGG; $n=5$ ) or with $100 \mu$ m blebbistatin (Bleb; $n=6$ ). Data are mean \pm SEM; ${ }^{* *} p<$ 0.01

MLCK, independent of CaM, and it shows very high specificity for MLCK with no inhibition of $\mathrm{Ca}^{2+} / \mathrm{CaM}$ kinase II or protein kinase A ( $\left.\mathrm{IC}_{50}=50 \mathrm{nM}\right)$ (Lukas et al., 1999). PTP was assessed at the calyx of Held synapse preloaded with $5 \mu \mathrm{M}$ MLCKip. Similar to the effects of pseudosubstrate peptide of MLCK on EPSPs in sympathetic neurons (Mochida et al., 1994), MLCKip significantly reduced the basal EPSC amplitude $[1.55 \pm 0.15 \mathrm{nA}(n=$ 19) vs $0.57 \pm 0.09 \mathrm{nA}(n=10) ; p<0.01$; aCSF + Kyn]. At 
A

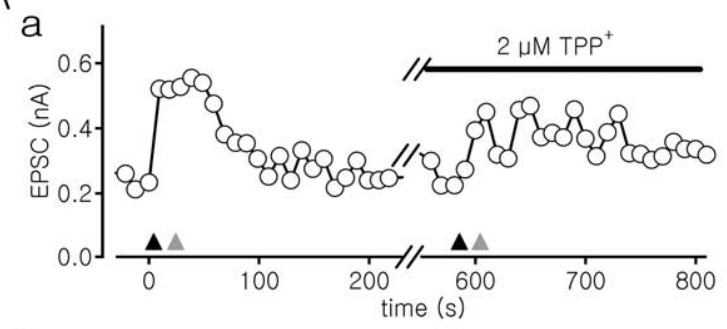

C

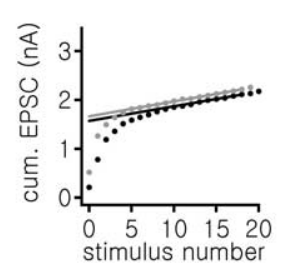

e

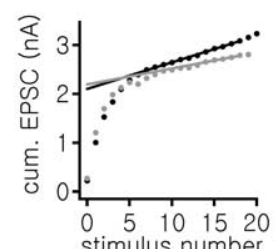

B

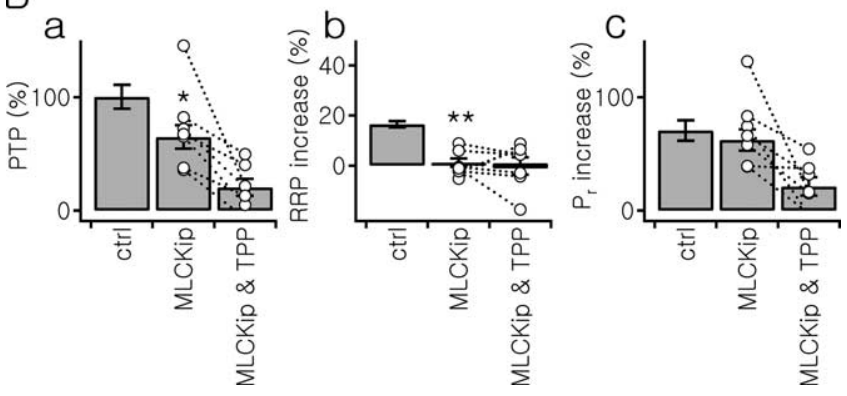

Figure 6. Additive inhibition of PTP by TPP ${ }^{+}$and MLCKip. Aa, Time course of PTP at the calyceal synapse preloaded with $5 \mu \mathrm{m}$ MLCKip (for $90 \mathrm{~s}$ ) before and after bath application of $\mathrm{TPP}^{+}$. Triangles indicate time points when TS $(100 \mathrm{~Hz}$ for $4 \mathrm{~s}$, black) or short AP trains (20 pulses at $100 \mathrm{~Hz}$; gray) were applied. $\boldsymbol{A} \boldsymbol{b}$ - $\boldsymbol{A e}$, First 10 EPSCs during (black) TS and $20 \mathrm{~s}$ after (gray) TS at the synapse preloaded with MLCKip before $(\boldsymbol{A} \boldsymbol{b})$ and after $(\boldsymbol{A d})$ superfusion of $2 \mu \mathrm{M}$ TPP ${ }^{+}$. Plots of cumulative (cum.) EPSC amplitudes during (black) and $20 \mathrm{~s}$ after (gray) TS at the same synapse are shown in $\boldsymbol{A c}$ and $\boldsymbol{A e}$ (black dots, during TS; gray dots, $20 \mathrm{~s}$ after TS). $\boldsymbol{B a}-\boldsymbol{B C}$, Mean values for PTP $(\boldsymbol{B a})$ and increases in the RRP size $(\boldsymbol{B} \boldsymbol{b})$ and $P_{r}(\boldsymbol{B C})$ at the synapse preloaded with $5 \mu \mathrm{M}$ MLCKip before and after bath application of TPP ${ }^{+}$. For comparison, statistical data under control conditions (ctrl, aCSF + Kyn; $n=19$ ) were reproduced from Figure $1 E$. Statistical difference between ctrl and MLCKip: ${ }^{*} p<0.05,{ }^{* *} p<0.01$, unpaired $t$ test.

synapses preloaded with MLCKip, the mean value for PTP was significantly lower than that at control synapses $(100.3 \pm 10.6 \mathrm{vs}$ $64.9 \pm 10.5 \%$; $p=0.04$ ) (Fig. $6 \mathrm{Ba}$ ). The lower PTP can be ascribed to the negligible posttetanic increase in the RRP size $(16.5 \pm 1.2$ vs $1.2 \pm 1.7 \% ; p<0.01$ ) (Fig. $6 B b)$, because MLCKip had less effect on the increase in $P_{\mathrm{r}}(70.6 \pm 9.0$ vs $62.2 \pm 9.4 \%$; $p=0.56)$ (Fig. $6 B c)$. These results strongly suggest that activation of MLCK is responsible for the posttetanic increase in RRP size at the calyx of Held synapse. Finally, we tested whether the effects of $\mathrm{TPP}^{+}$and MLCKip on PTP are additive. When $2 \mu \mathrm{M} \mathrm{TPP}{ }^{+}$was bath applied in the presence of MLCKip, PTP was further suppressed from $72.2 \pm 13.8$ to $20.5 \pm 7.4 \%(n=7 ; p<0.01$, paired $t$ test; aCSF + Kyn) (Fig. 6A, Ba). In the presence of MLCKip, $\mathrm{TPP}^{+}$reduced only the posttetanic increase in $P_{\mathrm{r}}$ from $70.2 \pm$ 12.0 to $21.4 \pm 8.0 \%(n=7 ; p=0.01)$ (Fig. $6 B c)$ with no effect on the RRP size (Fig. $6 \mathrm{Bb}$ ).
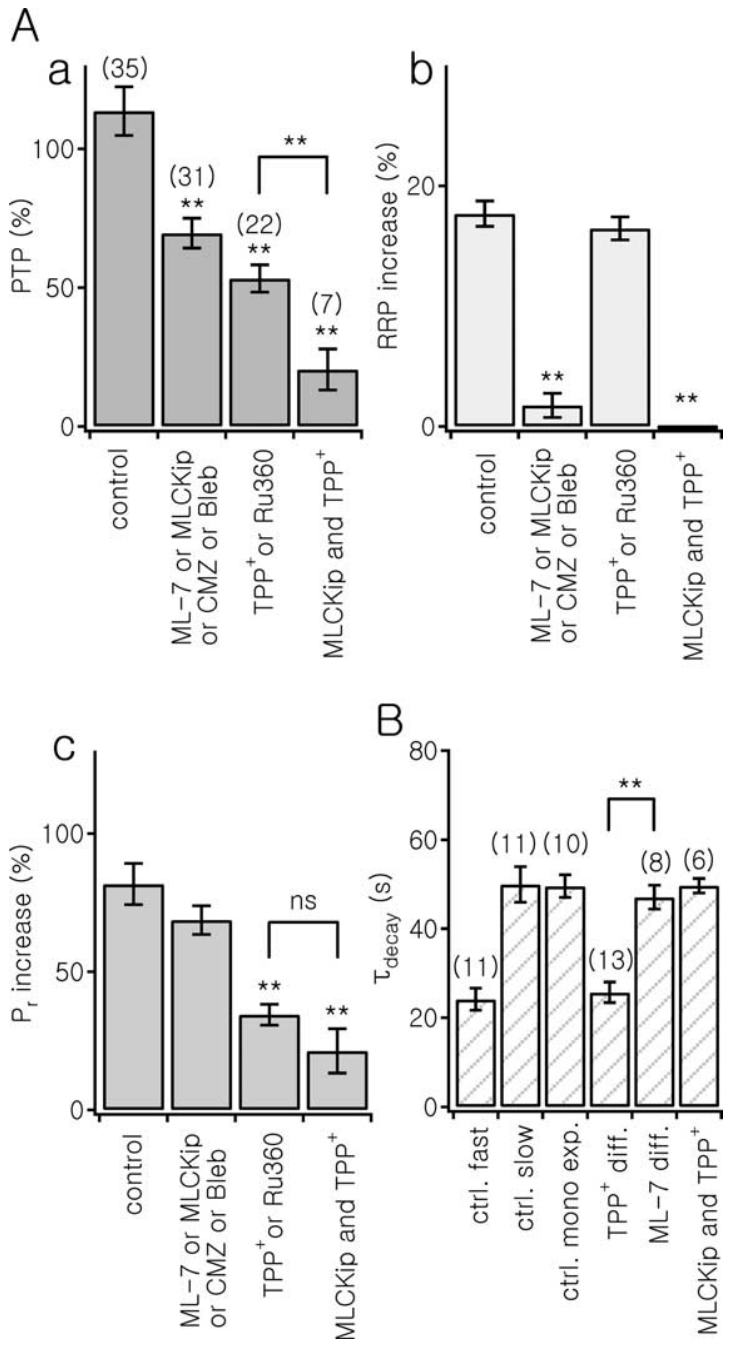

Figure 7. $A a-A c$, Summary for the effects of mitochondrial $\mathrm{Ca}_{\text {res }}$ inhibitors and MLCK inhibitors on PTP $(\boldsymbol{A a})$ and increases in the RRP size $(\boldsymbol{A b})$ and in $P_{r}(\boldsymbol{A c})$. There was no statistical difference between the effect of TPP ${ }^{+}$and that of Ru360, and the data were pooled. The data in the presence of ML-7, calmidazolium (CMZ), blebbistatin (Bleb), or MLCKip were pooled for the same reason. The statistical difference from a control value, ${ }^{* *} p<0.01$ (unpaired $t$ test). ns, Not significant. $\boldsymbol{B}$, Mean values for decay time constants of PTP under control conditions and the PTP components sensitive to TPP ${ }^{+}$(denoted by “TPP ${ }^{+}$diff") or ML7 (denoted by “ML-7 diff"). The decay time constant of TPP ${ }^{+}$-sensitive PTP (reproduced from Fig. 2C) was significantly faster than that of ML7-sensitive PTP $\left({ }^{* *} p<0.01\right)$. The decay time constant for PTP remaining after the combined treatment with TPP ${ }^{+}$and MLCKip was also similar to the slow time constant $(49.7 \pm 1.6 s ; n=6 ; p=0.96)$. Numbers in parentheses are the number of synapses investigated.

\section{Summary for the effects of $\mathrm{Ca}_{\text {res }}$ and MLCK inhibitors}

In Figure 7A, we summarize the effects of various inhibitors on PTP and increases in $P_{\mathrm{r}}$ and the RRP size. For comparison, we pooled data obtained with drugs targeting $\mathrm{Ca}_{\mathrm{res}}$ into one group and those obtained with drugs targeting MLCK into another group, because the observed effects were statistically not different. In addition we summarize the results obtained for combined application of MLCKip plus TPP ${ }^{+}$. The bar graphs in Figure 7A demonstrate that $P_{\mathrm{r}}$ and the RRP size are independently regulated during PTP by $\mathrm{Ca}_{\text {res }}$ and MLCK, respectively. Finally, we examined the decay time constants of PTP under control conditions and PTP components sensitive to TPP ${ }^{+}$or to ML-7 (Fig. 7B). We excluded from analysis synapses at which we lost the patch before PTP was fully decayed. At 11 of 21 synapses, the time course of control PTP was best fitted with biexponential function with fast 


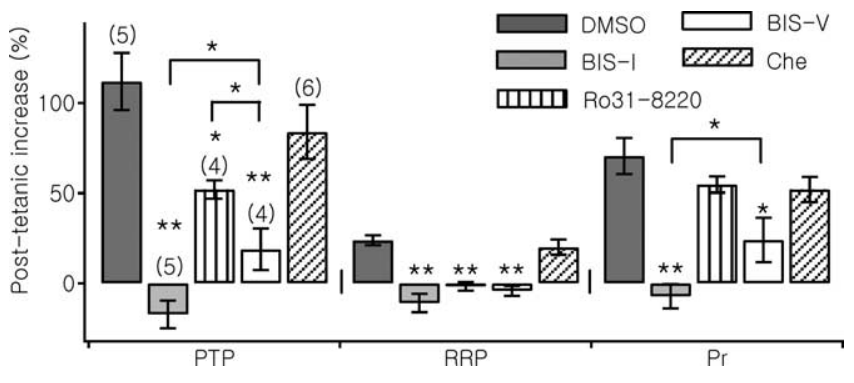

Figure 8. The effects of PKC inhibitors on PTP at the calyx of Held synapse. Mean values \pm SEM for PTP and relative changes in the RRP size and $P_{r}$ estimated at the synapse preloaded with DMSO (1:1000, v/v; $n=5), 2 \mu \mathrm{m}$ Bis-I $(n=5), 2 \mu \mathrm{m}$ R031-8220 ( $n=4), 2 \mu \mathrm{M}$ Bis-V $(n=4)$, or $5 \mu \mathrm{m}$ chelerythrine (Che; $n=6$ ) are shown. Note that the posttetanic increase in RRP size was abolished not only by Bis-I or Ro31-8220 but also by an inactive analog, Bis-V $(-4.16 \pm 2.77 \%$; $n=4 ; p<0.01)$. PTP at the synapse preloaded with $5 \mu$ m chelerythrine $(84.0 \pm 15.1 \% ; n=$ $6 ; p=0.23)$ was not different from that at the synapse with DMSO $(1 / 1000,112.0 \pm 15.9 \%$; $n=5)$. Statistical data in each condition were compared with data obtained from the synapse preloaded with DMSO unless specified otherwise. ${ }^{*} p<0.05$; ${ }^{* *} p<0.01$.

and slow time constants of $24.2 \pm 2.5 \mathrm{~s}$ and $50.0 \pm 4.0 \mathrm{~s}$, respectively $(n=11)$. At other synapses, PTP decayed monoexponentially with a time constant of $49.6 \pm 2.5 \mathrm{~s}(n=10)$. Regardless of whether the decay of PTP follows monoexponential or biexponential time course under control conditions, the PTP component sensitive to $\mathrm{TPP}^{+}$(denoted by "TPP diff" in Fig. $7 B$ ) decayed with a time constant $(25.7 \pm 2.3 \mathrm{~s} ; n=13)$ similar to the fast component of biexponential decay of control PTP (denoted by "ctrl fast" in Fig. $7 B$ ). In contrast, the decay time constant of the PTP component sensitive to ML-7 (denoted by "ML-7 diff"; $47.1 \pm 2.7 \mathrm{~s} ; n=8$ ) was similar to the slow time constant of control PTP $(p=0.59)$, which is distinct from that of $\mathrm{TPP}^{+}$. sensitive PTP. These results suggest that PTP at the calyx of Held synapse is composed of fast and slow decaying components that are regulated by $\mathrm{Ca}_{\text {res }}$ and MLCK, respectively.

\section{Role of protein kinase $\mathrm{C}$ in PTP}

The above results indicate that $\mathrm{Ca}_{\text {res }}$ and activation of MLCK can explain $\sim 80 \%$ of PTP. Recently, however, Korogod et al. (2007) have reported that PTP was abolished by protein kinase C (PKC) inhibitors, bisindolylmaleimide (Bis) drugs: Bis-I or Ro31-8220. To resolve this discrepancy, we compared PTP at the synapse preloaded with Bis drugs or an inactive analog, Bis- $\mathrm{V}$. The results are summarized in Figure 8, and EPSC traces are presented in supplemental Fig. S1 (available at www.jneurosci.org as supplemental material). Not only Bis-1 (2 $\mu \mathrm{M})$ and Ro31-8220 (2 $\mu \mathrm{M})$ but also Bis-V (2 $\mu \mathrm{M})$ significantly suppressed PTP (Fig. 8 ), indicating that PKC-independent mechanisms may be involved in the inhibitory effects of Bis drugs. Three drugs abolished the posttetanic increase in RRP size. Because posttetanic increase in $P_{\mathrm{r}}$ was significantly suppressed by Bis-I and Bis-V, but not by Ro31-8220, we tested the effect of these drugs on $\mathrm{Ca}_{\text {res }}$. Consistently, $\mathrm{Ca}_{\text {res }}$ was abolished by Bis-I and Bis-V, but not by Ro318220 (supplemental Fig. S1 $A-C$, available at www.jneurosci.org as supplemental material), suggesting that Bis-1 affects mitochondrial $\mathrm{Ca}^{2+}$ handling regardless of $\mathrm{PKC}$. The Bis drugs inhibit PKC by competing with ATP (Toullec et al., 1991). We tested the effects of chelerythrine, which inhibits PKC by covalently reacting with catalytic domain (Gopalakrishna et al., 1995). PTP persisted at the synapse preloaded with $5 \mu \mathrm{M}$ chelerythrine (Fig. 8; supplemental Fig. S1 D, available at www.jneurosci.org as supplemental material). PTP and the increase in $P_{\mathrm{r}}$ were slightly reduced in the presence of chelerythrine with no statistical significance
( $p=0.2$ and $p=0.15$, respectively). These results indicate that at least a part of inhibitory effects of Bis drugs may not be related to the inhibition of PKC.

\section{Discussion}

The principal findings of the present study are that (1) $\mathrm{Ca}_{\text {res }}$ is generated by posttetanic $\mathrm{Ca}^{2+}$ release via NCE subsequent to mitochondrial $\mathrm{Ca}^{2+}$ uptake during TS; (2) $\mathrm{Ca}_{\text {res }}$ and activation of MLCK independently mediate the posttetanic increases in $P_{\mathrm{r}}$ and the RRP size, respectively; and (3) the increase in RRP size lasted longer than $\mathrm{Ca}_{\text {res }}$, and constitutes a part of the slow decay phase of PTP at the calyx of Held synapse. These findings may provide an explanation for the long-standing question of why presynaptic $\mathrm{Ca}_{\text {res }}$ decays faster than PTP at mammalian central synapses. The involvement of MLCK in PTP is of general importance for shortterm synaptic plasticity.

Our results indicate that the increase in $P_{\mathrm{r}}$ contributes more to PTP than that in the RRP size. It should be noted, however, that the present study was done at immature synapses and at room temperature. Given that mitochondria in the calyx of Held compete for cytosolic $\mathrm{Ca}^{2+}$ with $\mathrm{Na}^{+} / \mathrm{Ca}^{2+}$ exchanger (Kim et al., 2005), developmental increase in $\mathrm{Na}^{+} / \mathrm{Ca}^{2+}$ exchanger activity (our unpublished observations) might limit mitochondrial uptake of $\mathrm{Ca}^{2+}$ during TS, a prerequisite for posttetanic $\mathrm{Ca}_{\text {res }}$. Moreover, the decay of the posttetanic $P_{\mathrm{r}}$ increase is preferentially accelerated at physiological temperature with little effect on the change in RRP size (Habets and Borst, 2007). Therefore, residual calcium, which subserves the increase in $P_{\mathrm{r}}$, might contribute less to PTP at mature synapses under physiological conditions.

\section{Mechanisms underlying the posttetanic increase in $\boldsymbol{P}_{\mathbf{r}}$}

Downstream mechanisms of $\mathrm{Ca}_{\text {res }}$ responsible for the increase in $P_{\mathrm{r}}$ are not clear. Saturation of endogenous $\mathrm{Ca}^{2+}$ buffers or increase in $\mathrm{Ca}^{2+}$ influx may underlie the increase in $P_{\mathrm{r}}$ (Felmy et al., 2003; Habets and Borst, 2006). Recently, Korogod et al. (2007) suggested that the latter is not sufficient to explain the $P_{\mathrm{r}}$ increase, and that activation of PKC contributes to the posttetanic $P_{\mathrm{r}}$ increase. The results in Figure 8, however, indicate that further experiments are necessary to clarify the role of PKC for PTP at the calyx of Held synapse.

Recently, we have reported that $\mathrm{Ca}_{\text {res }}$ derived from mitochondria and activation of PKC differentially contribute to PTP at large and small mossy fiber (MF) boutons of dentate granule cells (Lee et al., 2007). $\mathrm{Ca}_{\text {res}}$-dependent PTP has been observed only at exceptionally large presynaptic terminals such as NMJs, large mossy fiber boutons, and calyces of Held, suggesting a higher contribution of mitochondrial $\mathrm{Ca}^{2+}$ uptake during TS to the $\mathrm{Ca}^{2+}$ clearance at large presynaptic terminals than at small boutons. In the same paper, we also reported that PTP at large MF synapses was not inhibited by PKC inhibitors (chelerythrine and Ro31-8220). Interestingly, we observed that both Bis-I and Bis-V suppressed PTP at large MF synapses to a similar extent (our unpublished observations). This result is consistent with our observation that Bis-I and Bis-V suppress $\mathrm{Ca}_{\text {res }}$ at the calyx of Held (supplemental Fig. S1, available at www.jneurosci.org as supplemental material), and thus one should be cautious in interpreting the effects of Bis-I on PTP.

\section{Posttetanic increase in the RRP size}

It has been firmly established that desensitization and saturation of AMPA receptors contribute to the synaptic depression during strong synaptic activity (Trussell et al., 1993; Otis et al., 1996; Wong et al., 2003). The absolute value for the RRP size should be 
underestimated in the presence of $1 \mathrm{~mm}$ Kyn without cyclothiazide (CTZ). Consistent with Korogod et al. (2005), we found that in the presence of $1 \mathrm{mM}$ Kyn plus $100 \mu \mathrm{M} \mathrm{CTZ}$, the relative increase in estimates for the RRP size was negligible. However, when Kyn was elevated from 1 to $2 \mathrm{mM}$, RRP size estimates were significantly higher after induction of PTP (supplemental Fig. S2 B, available at www.jneurosci.org as supplemental material). This may indicate that the addition of $1 \mathrm{~mm}$ Kyn is insufficient to fully relieve AMPA receptor saturation during $100 \mathrm{~Hz}$ trains when CTZ is present in the bath. The decay time course of PTP was significantly slower in the presence of CTZ than that under control conditions, and the enhancement of EPSC did not subside at least until 5 min after TS; probably long-term potentiation of EPSC was induced (supplemental Fig. S2C, available at www. jneurosci.org as supplemental material). This result might be caused by nonspecific presynaptic effects of CTZ (Ishikawa and Takahashi, 2001). Therefore, we consider the use of CTZ problematic when studying the mechanisms of PTP at the calyx of Held synapse.

Because estimates of the RRP size from plots of cumulative EPSC amplitudes largely represent the fast-releasing pool (Schneggenburger et al., 2002; Sakaba, 2006), the TS-induced increase in the RRP size observed in the present study may represent an increase in the size of a fast-releasing pool rather than in a slow-releasing pool. In contrast, when the size of RRP was estimated by hypertonic sucrose, an increase in $P_{r}$, but not in the RRP size, was induced during augmentation in cultured hippocampal neurons (Stevens and Wesseling, 1999). The discrepancy may be ascribed to the fact that RRP estimates from cumulative EPSCs plots represent only a part of the RRP size reported by hypertonic sucrose (Moulder and Mennerick, 2005).

\section{Role of MLCK in the posttetanic increase in the RRP size}

It is not clear whether the mechanism responsible for replenishment of SV pools after depletion is similar to that for the posttetanic increase in RRP size. We showed that the posttetanic increase in RRP size was not affected by inhibition of $\mathrm{Ca}_{\text {res }}$ (Figs. $3 B$, $4 C)$. Moreover, no linear correlation was found between the amount of posttetanic $\mathrm{Ca}_{\text {res }}$ and the change in RRP size (Fig. 3D), indicating that $\mathrm{Ca}_{\text {res }}$ plays little role in posttetanic regulation of the RRP size. Therefore, activation of MLCK induced by the $\mathrm{Ca}^{2+}$ build-up during TS seems to be primarily responsible for the posttetanic increase in RRP size. This result is contrasted with the recent report that replenishing rate of fast-releasing pool is linearly dependent on $\left[\mathrm{Ca}^{2+}\right]_{\mathrm{i}}$ (Hosoi et al., 2007). Activation of myosin II by MLCK is thought to be a mediator for mobilization and recruitment of SVs at NMJs, where inhibition of MLCK caused intermittent failure of neurotransmission during TS (Polo-Prada et al., 2005). However, we did not observed any difference in late steady-state neurotransmission during $100 \mathrm{~Hz}$ stimulation in the presence of MLCK inhibitor or blebbistatin, suggesting that inhibition of MLCK has little effect on the vesicle recruitment during TS. Consistent with this view, Srinivasan et al. (2008) have recently reported that ML-7 affects neither the steady-state EPSCs nor the rate of recovery from synaptic depression. Therefore, we imagine that the mechanisms underlying posttetanic increase in the RRP size might be different from that underlying replenishment of fast SV pool after depletion.

\section{Possible physiological role of PTP in development of calyx of Held synapses}

The calyx of Held synapse is a sign-inverting synapse, for which synaptic transmission with high fidelity of spike timing is essen- tial. The task of the calyx of Held synapse might be interfered with by activity-dependent plastic changes of the synaptic connectivity, including PTP. Consistently, it has been reported that PTP is reduced as the synapse matures (Korogod et al., 2005). We consider a possibility that PTP contributes to the maturation of calyx of Held synapse. Recently, Joshi et al. (2007) reported that extrasynaptic NMDA receptors (NMDARs) are downregulated by pairing a depolarization of the postsynaptic neuron and burst stimulation of afferent axon fibers, probably by the mechanism of coincident activation of postsynaptic metabotropic glutamate receptors and NMDARs. It remains to be addressed whether such strong stimuli are possible under physiological conditions during a developmental period of hearing onset. We imagine that PTP at this synapse could provide an answer to this question, because an appreciable amount of PTP still remains at the age of hearing onset (Korogod et al., 2005). Sound stimulus elicits presynaptic bursts of high frequencies up to $600 \mathrm{~Hz}$ at the MNTB units in vivo (Kopp-Scheinpflug et al., 2003), suggesting that hearing onset will be accompanied with increased episodes of tetanic stimulation of MNTB neurons. It is conceivable that a prolonged tone burst might induce PTP of subsequent spontaneous synaptic activities. Enhanced glutamate release into synaptic cleft during PTP may facilitate the coincident activation and contribute to downregulation of extrasynaptic NMDARs.

\section{References}

Aiuchi T, Matsunaga M, Nakaya K, Nakamura Y (1985) Effects of probes of membrane potential on metabolism in synaptosome. Biochim Biophys Acta 843:20-24.

Awatramani GB, Price GD, Trussell LO (2005) Modulation of transmitter release by presynaptic resting potential and background calcium levels. Neuron 48:109-121.

Billups B, Forsythe ID (2002) Presynaptic mitochondrial calcium sequestration influences transmission at mammalian central synapses. J Neurosci 22:5840-5847.

Delaney KR, Tank DW (1994) A quantitative measurement of the dependence of short-term synaptic enhancement on presynaptic residual calcium. J Neurosci 14:5885-5902.

Delaney KR, Zucker RS, Tank DW (1989) Calcium in motor nerve terminals associated with posttetanic potentiation. J Neurosci 9:3558-3567.

Felmy F, Neher E, Schneggenburger R (2003) Probing the intracellular calcium sensitivity of transmitter release during synaptic facilitation. Neuron 37:801-811.

García-Chacón LE, Nguyen KT, David G, Barrett EF (2006) Extrusion of $\mathrm{Ca} 2+$ from mouse motor terminal mitochondria via a $\mathrm{Na}+/ \mathrm{Ca} 2+\mathrm{ex}-$ changer increases post-tetanic evoked release. J Physiol 574:663-675.

Gopalakrishna R, Chen ZH, Gundimeda U (1995) Modifications of cysteine-rich regions in protein kinase $\mathrm{C}$ induced by oxidant tumor promoters and enzyme-specific inhibitors. Methods Enzymol 252:132-146.

Habets RLP, Borst JGG (2005) Post-tetanic potentiation in the rat calyx of Held synapse. J Physiol 564:173-187.

Habets RLP, Borst JGG (2006) An increase in calcium influx contributes to post-tetanic potentiation at the rat calyx of Held synapse. J Neurophysiol 96:2868-2876

Habets RLP, Borst JGG (2007) Dynamics of the readily releasable pool during post-tetanic potentiation in the rat calyx of Held synapse. J Physiol 581:467-478.

Hosoi N, Sakaba T, Neher E (2007) Quantitative analysis of calciumdependent vesicle recruitment and its functional role at the calyx of Held synapse. J Neurosci 27:14286-14298.

Ishikawa T, Takahashi T (2001) Mechanisms underlying presynaptic facilitatory effect of cyclothiazide at the calyx of Held of juvenile rats. J Physiol 533:423-431.

Joshi I, Yang Y-M, Wang L-Y (2007) Coincident activation of metabotropic glutamate receptors and NMDA receptors (NMDARs) downregulates perisynaptic/extrasynaptic NMDARs and enhances high-fidelity neurotransmission at the developing calyx of Held synapse. J Neurosci 27:9989-9999. 
Kamiya H, Zucker RS (1994) Residual Ca2+ and short-term synaptic plasticity. Nature 371:603-606.

Kamm KE, Stull JT (2001) Dedicated myosin light chain kinases with diverse cellular functions. J Biol Chem 276:4527-4530.

Kim MH, Korogod N, Schneggenburger R, Ho WK, Lee SH (2005) Interplay between $\mathrm{Na}^{+} / \mathrm{Ca}^{2+}$ exchangers and mitochondria in $\mathrm{Ca}^{2+}$ clearance at the calyx of Held. J Neurosci 25:6057-6065.

Kirichok Y, Krapivinsky G, Clapham DE (2004) The mitochondrial calcium uniporter is a highly selective ion channel. Nature 427:360-364.

Kopp-Scheinpflug C, Lippe WR, Dörrscheidt GJ, Rübsamen R (2003) The medial nucleus of the trapezoid body in the gerbil is more than a relay: comparison of pre- and postsynaptic activity. J Assoc Res Otolaryngol $4: 1-23$.

Korogod N, Lou X, Schneggenburger R (2005) Presynaptic Ca ${ }^{2+}$ requirements and developmental regulation of posttetanic potentiation at the calyx of Held. J Neurosci 25:5127-5137.

Korogod N, Lou X, Schneggenburger R (2007) Posttetanic potentiation critically depends on an enhanced $\mathrm{Ca} 2+$ sensitivity of vesicle fusion mediated by presynaptic PKC. Proc Natl Acad Sci U S A 104:15923-15928.

Lee D, Lee KH, Ho WK, Lee SH (2007) Target cell-specific involvement of presynaptic mitochondria in post-tetanic potentiation at hippocampal mossy fiber synapses. J Neurosci 27:13603-13613.

Lukas TJ, Mirzoeva S, Slomczynska U, Watterson DM (1999) Identification of novel classes of protein kinase inhibitors using combinatorial peptide chemistry based on functional genomics knowledge. J Med Chem 42:910-919.

Mochida S, Kobayashi H, Matsuda Y, Yuda Y, Muramoto K, Nonomura Y (1994) Myosin II is involved in transmitter release at synapses formed between rat sympathetic neurons in culture. Neuron 13:1131-1142.

Moulder KL, Mennerick S (2005) Reluctant vesicles contribute to the total readily releasable pool in glutamatergic hippocampal neurons. J Neurosci 25:3842-3850.

Otis T, Zhang S, Trussell LO (1996) Direct measurement of AMPA receptor desensitization induced by glutamatergic synaptic transmission. J Neurosci 16:7496-7504.

Polo-Parada L, Plattner F, Bose C, Landmesser LT (2005) NCAM 180 acting via a conserved C-terminal domain and MLCK is essential for effective transmission with repetitive stimulation. Neuron 46:917-931.

Regehr WG, Delaney KR, Tank DW (1994) The role of presynaptic calcium in short-term enhancement at the hippocampal mossy fiber synapse. J Neurosci 14:523-537.

Rozov A, Burnashev N, Sakmann B, Neher E (2001) Transmitter release modulation by intracellular Ca2+ buffers in facilitating and depressing nerve terminals of pyramidal cells in layer $2 / 3$ of the rat neocortex indi- cates a target cell-specific difference in presynaptic calcium dynamics. J Physiol 531:807-826.

Ryan TA (1999) Inhibitors of myosin light chain kinase block synaptic vesicle pool mobilization during action potential firing. J Neurosci 19:1317-1323.

Sakaba T (2006) Roles of the fast-releasing and slowly releasing vesicles in synaptic transmission at the calyx of Held. J Neurosci 26:5863-5871.

Schneggenburger R, Meyer AC, Neher E (1999) Released fraction and total size of a pool of immediately available transmitter quanta at a calyx synapse. Neuron 23:399-409.

Schneggenburger R, Sakaba T, Neher E (2002) Vesicle pools and short-term synaptic depression: lessons from a large synapse. Trends Neurosci 25:206-212.

Srinivasan G, Kim JH, von Gersdorff H (2008) The pool of fast releasing vesicles is augmented by myosin light chain kinase inhibition at the calyx of Held synapse. J Neurophysiol 99:1810-1824.

Stevens CF, Wesseling JF (1999) Augmentation is a potentiation of the exocytotic process. Neuron 22:139-146.

Takagishi Y, Futaki S, Itoh K, Espreafico EM, Murakami N, Murata Y, Mochida S (2005) Localization of myosin II and V isoforms in cultured rat sympathetic neurones and their potential involvement in presynaptic function. J Physiol 569:195-208.

Tang Y, Zucker RS (1997) Mitochondrial involvement in post-tetanic potentiation of synaptic transmission. Neuron 18:483-491.

Tokuoka H, Goda Y (2006) Myosin light chain kinase is not a regulator of synaptic vesicle trafficking during repetitive exocytosis in cultured hippocampal neurons. J Neurosci 26:11606-11614.

Toullec D, Pianetti P, Coste H, Bellevergue P, Grand-Perret T, Ajakane M, Baudet V, Boissin P, Boursier E, Loriolle F (1991) The bisindolylmaleimide GF $109203 \mathrm{X}$ is a potent and selective inhibitor of protein kinase C. J Biol Chem 266:15771-15781.

Trussell LO, Zhang S, Raman IM (1993) Desensitization of AMPA receptors upon multiquantal neurotransmitter release. Neuron 10:1185-1196.

Verstreken P, Ly CV, Venken KJT, Koh T-W, Zhou Y, Bellen HJ (2005) Synaptic mitochondria are critical for mobilization of reserve pool vesicles at Drosophila neuromuscular junctions. Neuron 47:365-378.

Wingrove DE, Gunter TE (1986) Kinetics of mitochondrial calcium transport. II. A kinetic description of the sodium-dependent calcium efflux mechanism of liver mitochondria and inhibition by ruthenium red and by tetraphenylphosphonium. J Biol Chem 261:15166-15171.

Wong AYC, Graham BP, Billups B, Forsythe ID (2003) Distinguishing between presynaptic and postsynaptic mechanisms of short-term depression during action potential trains. J Neurosci 23:4868-4877.

Zucker RS, Regehr WG (2002) Short-term synaptic plasticity. Annu Rev Physiol 64:355-405. 